\section{Potassium Nutrition in Lilium: Critical Concentrations, Photosynthesis, Water Potential, Leaf Anatomy, and Nutrient Status}

\author{
Enoc Barrera-Aguilar \\ Centro de Investigación en Química Aplicada, Boulevard Enrique Reyna \\ 140, Saltillo, Coah., México \\ Luis A. Valdez-Aguilar ${ }^{1}$ \\ Departamento de Horticultura, Universidad Autónoma Agraria Antonio \\ Narro, Buenavista, Saltillo, Coah., México
}

Ana M. Castillo-González

Instituto de Horticultura, Universidad Autónoma Chapingo, Carr. MéxicoTexcoco Km. 36.5, Chapingo, México

Andrew D. Cartmill

Pioneer Farm, School of Agriculture, University of Wisconsin-Platteville, 1 University Plaza, Platteville, WI

Donita L. Cartmill

School of Agriculture, University of Wisconsin-Platteville, 1 University Plaza, Platteville, WI

\section{Edilberto Avitia-García}

Instituto de Horticultura. Universidad Autónoma Chapingo, Carr. MéxicoTexcoco Km. 36.5, Chapingo, México

\section{Luis Ibarra-Jímenez}

Centro de Investigación en Química Aplicada, Boulevard Enrique Reyna 140, Saltillo, Coah., México

Additional index words. cut flowers, hydroponics, plant nutrition, segmented analysis, soilless culture

\begin{abstract}
The present study was conducted to determine the critical optimum and toxic concentrations of potassium (K) using segmented analysis and its relationship with some physiological, anatomical, and nutritional responses to increasing $K$ in hydroponically grown Lilium sp. L. cv. Arcachon. Plants were fertigated with nutrient solutions containing $K\left(K_{e x t}\right)$ at $0,2.5,5.0,7.5,12.5,17.5,22.5$, and $30 \mathrm{mmol} \cdot \mathrm{L}^{-1}$. Maximum flower diameter occurred when, on a dry mass basis, shoot $K\left(K_{\text {int }}\right)$ ranged from 504 to $892 \mathrm{mmol} \cdot \mathrm{kg}^{-1}$; however, a lower $K_{\text {int }}$ was required to obtain maximum biomass accumulation and shoot length $\left(384\right.$ and $303 \mathrm{mmol} \cdot \mathrm{kg}^{-1}$, respectively). Potassium increased in all plant organs as $\mathrm{K}$ in the nutrient solution increased. Nitrogen increased in young leaves and magnesium $(\mathrm{Mg})$ decreased as $K_{\text {ext }}$ increased. Concentrations of $K_{\text {ext }}$ from 5 to $17.5 \mathrm{mmol} \cdot \mathrm{L}^{-1}$ increased the size of chlorenchyma and occlusive cells; however, metaxylem vessels were unaffected. Net photosynthetic rate was higher in young leaves, whereas water potential increased in both young and mature leaves when $K_{\text {ext }}$ was greater than $22.5 \mathrm{mmol} \cdot \mathrm{L}^{-1}$. Critical concentrations varied according to the growth parameter. Optimum $K_{\text {int }}$ ranged from 303 to $384 \mathrm{mmol} \cdot \mathrm{kg}^{-1}$ for vegetative parts, whereas parameters related with flower growth ranged from 427 to $504 \mathrm{mmol} \cdot \mathrm{kg}^{-1}$. Concentration of $504 \mathrm{mmol} \cdot \mathrm{kg}^{-1} \mathrm{~K}_{\mathrm{int}}$ was associated with optimum growth for all the parameters assessed, whereas a $K_{\text {int }}$ greater than $864 \mathrm{mmol} \cdot \mathrm{kg}^{-1}$ was associated with a decline in growth; thus, these concentrations were considered as the critical optimum and critical toxicity levels, respectively. The optimum and toxicity critical $K_{\text {int }}$ were estimated when $K_{e x t}$ in the nutrient solutions was 5.6 and $13.6 \mathrm{mmol} \cdot \mathrm{L}^{-1}$, respectively.
\end{abstract}

Received for publication 26 Aug. 2013. Accepted for publication 15 Oct. 2013.

${ }^{1}$ To whom reprint request should be addressed; e-mail luisalonso.valdez@uaaan.mx. solutes within the plant (Mengel and Kirkby, 2001). Potassium deficiency affects primary and secondary metabolism (Armengaud et al., 2009), leading to increased susceptibility to pest and disease (Amtmann et al., 2008), leaf edge scorching, and reduced growth and marketability of a range of ornamental species (Karimi et al., 2009; Wang, 2007; Yi Lin and Ming Yeh, 2008).

Knowledge of critical nutrient demands is of major importance for the design of sustainable horticultural production systems. Nutrient requirement is defined in terms of a critical concentration derived from growth or yield response curves over a wide range of nutrient supply (Genc et al., 2002). The response curves are usually separated into four phases: 1) a deficiency phase in which plant growth increases markedly with slight incremental increases in nutrient concentration; 2) a sufficiency phase in which growth is maximized (Salifu and Timmer, 2003); 3) an adequate phase in which further growth is not achieved despite the increase in nutrient availability as a result of luxury consumption; and 4) a toxicity phase in which nutrient concentration continues to increase but plant growth declines (Isaac and Kimaro, 2011; Marschner, 1995; Salifu and Timmer, 2003). Nutrient concentration is defined as sufficient or as the critical optimum concentration (Marschner, 1995) when plants exhibit $90 \%$ to $95 \%$ of maximum growth or yield (Ulrich and Hills, 1993), whereas the concentration at which growth declines is considered as the critical toxicity level (Marschner, 1995).

Lilium (Lilium sp.) is a widely cultivated ornamental geophyte. Studies on Lilium nutrition have been reported (Argo and Biernbaum, 1994) and tissue nutrient levels $\left(\mathrm{mmol} \cdot \mathrm{kg}^{-1}\right)$ of high-quality lilium plants are 1700 to 2900 nitrogen $(\mathrm{N}), 32$ to 226 phosphorus $(\mathrm{P}), 512$ to $1279 \mathrm{~K}, 50$ to 100 calcium $(\mathrm{Ca})$, and 125 to $833 \mathrm{Mg}$ (Dole and Wilkins, 2005). However, there is little information available on lilium cultivation for cut flower purposes in hydroponic systems. Ornamental geophytes pose a challenge for plant nutrition research because the bulb stores reserves of carbohydrates and mineral elements; thus, the response to external nutrient concentrations may not be comparable to that of non-geophytic species. The present study was conducted to determine the response of Lilium sp. L cv. Arcachon in perlite cultures to varying $\mathrm{K}$ levels in the nutrient solution with the objective of defining the critical internal and external $\mathrm{K}$ concentration. Because no reports have been published, on the present research we also assessed the relationship of $\mathrm{K}$ nutrition with leaf water potential $\left(\psi_{\mathrm{w}}\right)$, photosynthetic rate, leaf anatomy, and plant nutritional status.

\section{Materials and Methods}

Cultural conditions and plant material. The study was conducted under greenhouse conditions in northeast México (lat. $25^{\circ} 27^{\prime}$ $\mathrm{N}$, long. $101^{\circ} 02^{\prime} \mathrm{W}, 1610 \mathrm{~m}$ above sea level); average minimum/maximum temperature and relative humidity for experiment duration 
were $12.4 / 27.2{ }^{\circ} \mathrm{C}$ and $46 \% / 75 \%$, respectively, and average photosynthetically active radiation $(P A R)$ measured at solar noon was $461 \mu \mathrm{mol} \cdot \mathrm{m}^{-2} \cdot \mathrm{s}^{-1}$.

Twelve, previously disinfected (benomyl; 1 g. $\mathrm{L}^{-1}$ ), lilium (Lilium sp. cv. Arcachon) bulbs, 16 to $18 \mathrm{~cm}$ in circumference, were planted in 39-L rigid plastic containers with a drainage hole for retrieval of the nutrient solution. Each container was considered an experimental unit. In the container, the bulbs were uniformly distributed on a $\approx 7.5$-cm bed of perlite and covered to a height of $\approx 7.5 \mathrm{~cm}$ above the bulb tip. Water-holding capacity of perlite was $33 \%(\mathrm{v} / \mathrm{v})$, air-filled pore space $64 \%$, and an apparent density $0.25 \mathrm{~g} \cdot \mathrm{cm}^{-3}$.

Potassium application. Experimental units were fertigated with nutrient solutions prepared with distilled water to supply $\mathrm{K}$ at $0,2.5,5.0,7.5,12.5,17.5,22.5$, and 30 mmol. $\mathrm{L}^{-1}$. Compositions, $\mathrm{pH}$, and electrical conductivity (EC) of the nutrient solutions are shown in Table 1 and were prepared with $\mathrm{Ca}\left(\mathrm{NO}_{3}\right)_{2} \cdot 5 \mathrm{H}_{2} \mathrm{O}$ (Fisher Scientific, Pittsburgh, PA), $\mathrm{CaSO}_{4} \cdot 2 \mathrm{H}_{2} \mathrm{O}$ (Sigma, St. Louis, MO), $\mathrm{KNO}_{3}$ (Sigma), $\mathrm{KH}_{2} \mathrm{PO}_{4}$ (Sigma), $\mathrm{K}_{2} \mathrm{SO}_{4}$ (Sigma), $\mathrm{Mg}\left(\mathrm{NO}_{3}\right)_{2} \cdot 6 \quad \mathrm{H}_{2} \mathrm{O} \quad$ (Sigma), $\mathrm{MgSO}_{4} \cdot 7 \mathrm{H}_{2} \mathrm{O}$ (Sigma), Fe-DTPA (Becker Underwood, Inc., Ames, IA), $\mathrm{CuSO}_{4} \cdot 5 \mathrm{H}_{2} \mathrm{O}$ (Fisher Scientific, Fair Lawn, NJ), $\mathrm{ZnSO}_{4} \cdot 5 \mathrm{H}_{2} \mathrm{O}$ (Matheson Coleman \& Bell Manufacturing Chemists), $\mathrm{MnSO}_{4} \cdot \mathrm{H}_{2} \mathrm{O}$ (Sigma), and $\mathrm{H}_{3} \mathrm{BO}_{3}$ (Spectrum Chemical Mfg. Corp., Gardena, CA).

Fertigation was applied through a drip irrigation system (six emitters per experimental unit) designed to collect the leachate for reuse. Initially, plants were irrigated for 10 min $(\approx 3.6 \mathrm{~L})$ three times a day; however, as the plants increased in size, irrigation frequency was increased to six times a day. Evapotranspirated water was replenished daily to each stock tank of nutrient solution with distilled water and the nutrient solutions were replaced at weekly intervals.

Photosynthesis and leaf water potential. Net photosynthesis was measured (LI-6200; LI-COR, Inc., Lincoln, NE) at $1200 \mathrm{HR} 54 \mathrm{~d}$ after planting on young (the third fully developed leaf from top to bottom) and mature (sampled in the lower third of plant canopy) leaves. Average $P A R, \mathrm{CO}_{2}$ concentration, and temperature were $400 \mu \mathrm{mol} \cdot \mathrm{m}^{-2} \cdot \mathrm{s}^{-1}, 355 \mathrm{ppm}$, and $25.5{ }^{\circ} \mathrm{C}$, respectively. Three measurements on each leaf from one plant per experimental unit were recorded. Water potential of two young and two mature leaves per plant were measured (Scholander Pressure Chamber; Soil Moisture Equipment Corp., Santa Barbara, CA). Relative chlorophyll content (SPAD index; Konica Minolta, Japan) was measured in three mature (lower two-thirds of plant canopy) and three young leaves (upper one-third of plant canopy) per plant.

Assessment of plant growth and nutrient status. Growth measurements were recorded at harvest (60 d after planting) in five randomly selected plants per experimental unit, including shoot length (substrate to the top of the inflorescence), flower diameter (measured when the first two flowers were fully expanded), and leaf area (LI-3100; LI-COR, Inc.).

In addition, five plants per experimental unit were separated into roots, bulbs, stems, young and mature leaves, and flowers; washed twice with distilled water; and placed in an oven at $75^{\circ} \mathrm{C}$ for $72 \mathrm{~h}$ (120 h for bulbs). Dry mass (DM) was recorded for each plant part and shoot DM was calculated by adding the DM of stems, leaves, and flowers. Plant tissues were ground to pass a 40-mesh sieve (A-10; Tekmar, IKA Labortechnik, Germany). Tissues were digested in a 2:1 mixture of $\mathrm{H}_{2} \mathrm{SO}_{4}$ : $\mathrm{HClO}_{4}$ and $2 \mathrm{~mL} 30 \% \mathrm{H}_{2} \mathrm{O}_{2}$. The digested samples were analyzed for $\mathrm{N}$ with the MicroKjeldahl procedure (Bremner, 1996) and for $\mathrm{K}, \mathrm{P}, \mathrm{Ca}$, and $\mathrm{Mg}$ with an inductively coupled plasma emission spectrometer (Model Liberty; VARIAN, Santa Clara, CA) (Soltanpour et al., 1996).

Effect of potassium concentration on leaf anatomy. The transversal middle portion of young leaves from plants irrigated with solutions containing $0,5,12.5,17.5$, and 30 $\mathrm{mmol} \cdot \mathrm{L}^{-1} \mathrm{~K}$ were sampled at experiment termination, processed, and cut into $10-\mu \mathrm{m}$ transversal slices with a rotary microtome (Jung Histocut, Model 820; Leica, Rankin Biomedical Co., Holly, MI). Leaf thickness, number, and diameter of metaxylem vessels and the number of spongy parenchyma cells were measured with an optic microscope (Olympus BX60; Olympus Co., Japan) and an image analyzer (Image-PRO Plus Version 7.0; Media Cybernetics, Bethesda, MD). Stomata density, length, and width of occlusive cells were measured on epidermal samples close to the central vein on the abaxial surface of the same leaves. Leaf thickness was measured at a distance of $780 \mu \mathrm{m}$ from the center of the first vascular bundle closest to the central vein, whereas the number and diameter of metaxylem vessels were measured on the same vascular bundle. The number of spongy parenchyma cells was measured close to the leaf margin.

Statistical design. Four replicates of each experimental unit (container with 12 bulbs) were distributed in a complete randomized block design with eight levels of K. Significance of $\mathrm{K}$ in the nutrient solution $\left(\mathrm{K}_{\mathrm{ext}}\right)$ on leaf anatomy, nutrient status, and leaf $\psi_{\mathrm{w}}$ was determined using analysis of variance and linear, quadratic, or cubic trend analysis. Remaining data were modeled with piecewise segmented analysis (NLIN procedure) (SAS Version 8.0; SAS Institute, Cary, NC) to define the responses of plants to the resulting $\mathrm{K}$ shoot concentration $\left(\mathrm{K}_{\mathrm{int}}\right)$. The models estimated the optimum and toxicity critical levels at which the highest and lowest $\mathrm{K}$ internal concentrations were associated with increasing or toxic effects on plant growth, respectively.

\section{Results}

Potassium in the shoot increased linearly when $\mathrm{K}_{\mathrm{ext}}$ increased from 0 to $12.5 \mathrm{mmol} \cdot \mathrm{L}^{-1}$ (Fig. 1); however, higher $\mathrm{K}_{\mathrm{ext}}$ induced an additional increase in $\mathrm{K}_{\text {int }}$ but at a lower rate. The inflection point at which the rate of $\mathrm{K}_{\text {int }}$ concentration shifted was estimated at 12 $\mathrm{mmol} \cdot \mathrm{L}^{-1} \mathrm{~K}_{\text {ext }}$.

Maximum flower diameter was estimated by segmented analysis at $24.7 \mathrm{~cm}$ when $\mathrm{K}_{\mathrm{int}}$ ranged from 504 to $892 \mathrm{mmol} \cdot \mathrm{kg}^{-1}$ (Fig. 2A). Shoot $\mathrm{K}$ less than $504 \mathrm{mmol} \cdot \mathrm{kg}^{-1}$ and greater than $892 \mathrm{mmol} \cdot \mathrm{kg}^{-1}$ were associated with decreased flower size. Maximum shoot DM was estimated at $42.9 \mathrm{~g}$ when $\mathrm{K}_{\mathrm{int}}$ ranged from 384 to $864 \mathrm{mmol} \cdot \mathrm{kg}^{-1}$ (Fig. 2B); concentrations below and above this range were associated with decreased shoot DM accumulation.

Maximum shoot length was estimated when $\mathrm{K}_{\text {int }}$ ranged from 303 to $949 \mathrm{mmol} \cdot \mathrm{kg}^{-1}$ (Fig. 2C). Internal $\mathrm{K}$ less than $303 \mathrm{mmol} \cdot \mathrm{kg}^{-1}$ or greater than $949 \mathrm{mmol} \cdot \mathrm{kg}^{-1}$ were associated with decreased shoot length. Other growth attributes such as leaf area and flower dry mass were also affected by $\mathrm{K}_{\text {int }}$ (models not shown). Maximum flower DM, shoot length, leaf area, shoot DM, and flower diameter were observed at varying $\mathrm{K}_{\text {int }}$ concentrations (Fig. 2D)

Trend analysis suggests that $\mathrm{N}$ increased in roots and mature and young leaves (Table 2; Fig. 3A), but in the bulbs, there was a decreasing trend as $\mathrm{K}_{\mathrm{ext}}$ increased in the

Table 1. Nutrient solutions $\mathrm{pH}$, electrical conductivity (EC), and macronutrient and micronutrient composition with increasing potassium (K) concentration.

\begin{tabular}{|c|c|c|c|c|c|c|c|c|c|c|c|c|c|}
\hline \multirow{2}{*}{$\begin{array}{l}\mathrm{K} \text { in the nutrient } \\
\text { solution }\left(\mathrm{mmol} \cdot \mathrm{L}^{-1}\right)\end{array}$} & \multirow{2}{*}{$\mathrm{pH}$} & \multirow{2}{*}{$\mathrm{EC}\left(\mathrm{dS} \cdot \mathrm{m}^{-1}\right)$} & \multirow{2}{*}{$\mathrm{NO}_{3}{ }^{-} \mathrm{N}$} & \multicolumn{10}{|c|}{ Nutrient solution composition } \\
\hline & & & & $\mathrm{H}_{2} \mathrm{PO}_{4}^{-}$ & $\mathrm{K}$ & Calcium & Magnesium & $\mathrm{SO}_{4}{ }^{2-}$ & Boron & Manganese & Zinc & Copper & Iron \\
\hline 0 & 6.2 & 1.52 & 15 & 0.5 & 0.0 & 9.0 & 7.0 & 1.0 & 0.5 & 0.5 & 0.05 & 0.02 & 5 \\
\hline 2.5 & 6.2 & 1.65 & 15 & 0.5 & 2.5 & 9.0 & 6.0 & 2.0 & 0.5 & 0.5 & 0.05 & 0.02 & 5 \\
\hline 5 & 6.3 & 1.77 & 15 & 0.5 & 5.0 & 9.0 & 6.0 & 4.5 & 0.5 & 0.5 & 0.05 & 0.02 & 5 \\
\hline 7.5 & 6.4 & 1.97 & 15 & 0.5 & 7.5 & 9.0 & 6.0 & 7.0 & 0.5 & 0.5 & 0.05 & 0.02 & 5 \\
\hline 17.5 & 6.5 & 2.49 & 15 & 0.5 & 17.5 & 9.0 & 6.0 & 17.0 & 0.5 & 0.5 & 0.05 & 0.02 & 5 \\
\hline
\end{tabular}


nutrient solution. Highest $\mathrm{N}$ concentrations were observed in mature and young leaves when $\mathrm{K}_{\text {ext }}$ was 12.5 to $22.5 \mathrm{mmol} \cdot \mathrm{L}^{-1}$; however, increasing $\mathrm{K}_{\text {ext }}$ to $30 \mathrm{mmol} \cdot \mathrm{L}^{-1}$ decreased leaf $\mathrm{N}$ (Fig. 3A).

Phosphorus increased after a quadratic trend in roots, bulbs, and stems as $\mathrm{K}_{\mathrm{ext}}$ concentration increased (Table 2; Fig. 3B); however, young leaves exhibited a linear decrease at high $\mathrm{K}_{\mathrm{ext}}$ concentrations. Potassium increased in all plant parts (Table 2); however, the increase was marginal in bulbs and greatest in young leaves (Fig. 3C).

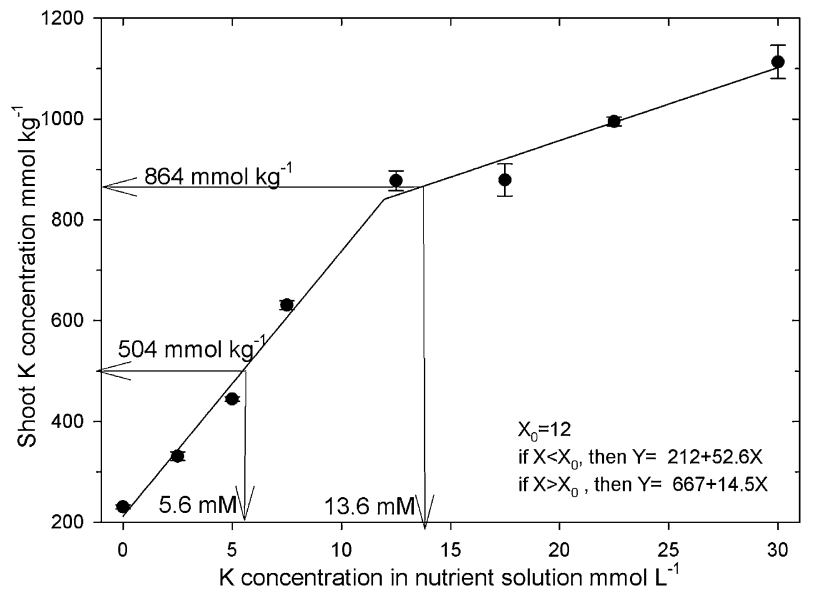

Fig. 1. Segmented analysis of the effect of external potassium $(\mathrm{K})$ concentration on internal $\mathrm{K}$ in shoots of Lilium sp. L. cv. Arcachon. Segmented analysis showed an inflection point where K accumulation changed slopes at $12 \mathrm{mmol} \cdot \mathrm{L}^{-1}$ of external $\mathrm{K}\left(\mathrm{X}_{0}\right)$. Linear models that apply when $\mathrm{X}$ is lower or higher than the inflection point are shown. Arrows indicate the predicted critical optimum and toxicity internal concentrations and the corresponding external $\mathrm{K}$. Bars represent the SEM.
Calcium was higher in roots of plants irrigated with solutions containing high $\mathrm{K}_{\text {ext }}$; however, $\mathrm{Ca}$ increased at higher $\mathrm{K}_{\text {ext }}$ levels in mature leaves, whereas in young leaves, it increased when $\mathrm{K}_{\text {ext }}$ increased from 5 to 12.5 mmol. $\mathrm{L}^{-1}$ (Table 2; Fig. 3D). Increasing internal $\mathrm{Ca}$ concentration was associated with an increase in $\mathrm{Mg}\left(\mathrm{Ca}=33.6+0.85 \mathrm{Mg}, R^{2}=\right.$ $0.601)$ and $\mathrm{N}\left(\mathrm{Ca}=39.5+0.15 \mathrm{~N}, R^{2}=\right.$ 0.780 ), whereas an increase in $\mathrm{K}_{\text {int }}$ was associated with an increase in $\mathrm{N}(\mathrm{N}=162+$ $48.7 \mathrm{~K}, R^{2}=0.840$ ) in young leaves.

In all plant parts, there was a linear or quadratic decrease in $\mathrm{Mg}$ as $\mathrm{K}_{\text {ext }}$ was increased from 0 to $7.5 \mathrm{mmol} \cdot \mathrm{L}^{-1}$ in bulbs, stems, and roots or from 0 to $12.5 \mathrm{mmol} \cdot \mathrm{L}^{-1}$ in mature and young leaves (Table 2; Fig. 3E). There were no further decreases at higher $\mathrm{K}_{\mathrm{ext}}$ concentration.

A quadratic or cubic increase in leaf thickness and length of occlusive cells was observed when $\mathrm{K}_{\text {ext }}$ increased from 5 to 12.5 or $17.5 \mathrm{mmol} \cdot \mathrm{L}^{-1}$ (Table 3 ); however, stomata and chlorenchyma cell count decreased when $\mathrm{K}_{\text {ext }}$ was increased, suggesting larger cells per unit area. At $30 \mathrm{mmol} \cdot \mathrm{L}^{-1} \mathrm{~K}_{\text {ext }}$, the number of both cell types was similar to that of plants with $0 \mathrm{mmol} \cdot \mathrm{L}^{-1}$ of $\mathrm{K}_{\mathrm{ext}}$. The number and diameter of metaxylem vessels as well as occlusive cells width were unaffected by $\mathrm{K}_{\mathrm{ext}}$ (Table 3).
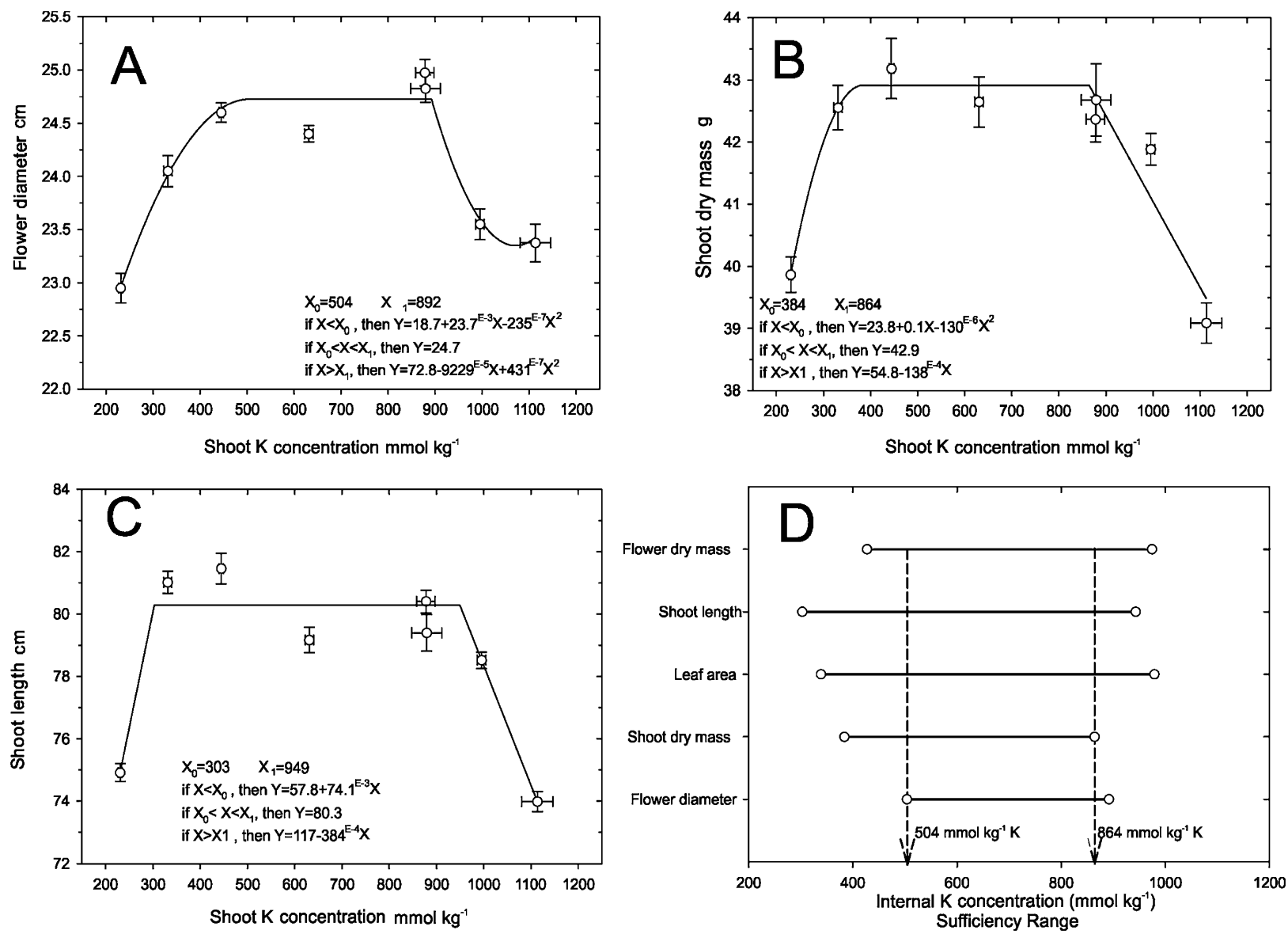

Fig. 2. Predicted response curves with segmented analysis of growth parameters as affected by internal potassium (K) in shoots of Lilium sp. L. cv. Arcachon fertigated with 0 to $30 \mathrm{mmol} \cdot \mathrm{L}^{-1} \mathrm{~K}(\mathbf{A}-\mathbf{C})$. Sufficiency zones are indicated by the plateau of the line; critical optimum $\left(\mathrm{X}_{0}\right.$, left side of the plateau) and critical toxicity $\left(\mathrm{X}_{1}\right.$, right side of the plateau) concentrations are also delineated. Bars represent the SEM. Potassium sufficiency zones are predicted for all the growth parameters assessed $(\mathbf{D})$. 
Table 2. Significance of trends of nutrient concentration in plant tissues of Lilium sp. L. cv. Arcachon fertigated with increasing concentrations of potassium $(\mathrm{K})$ in the nutrient solution.

\begin{tabular}{|c|c|c|c|c|c|}
\hline $\begin{array}{l}\text { Nutrient in } \\
\text { plant tissues }\end{array}$ & $\operatorname{Root}^{2}$ & Bulb & Stem & Mature leaves & Young leaves \\
\hline Nitrogen & $\mathrm{L}^{* * *} \mathrm{Q}^{* * *}$ & $\mathrm{~L}^{*} \mathrm{Q}^{* *}$ & NS & $\mathrm{C}^{*}$ & $\mathrm{~L}^{* * *} \mathrm{Q} * * * \mathrm{C}^{* *}$ \\
\hline Phosphorus & $\mathrm{L}^{* * *} \mathrm{Q}^{* * *} \mathrm{C}^{*}$ & $\mathrm{Q}^{*}$ & $\mathrm{~L}^{* * *} \mathrm{Q} * * *$ & $\mathrm{Q}^{*}$ & $\mathrm{~L}^{* * *}$ \\
\hline $\mathrm{K}$ & $\mathrm{L}^{* * *} \mathrm{Q}^{*}$ & $\mathrm{~L}^{* * *}$ & $\mathrm{~L}^{* * *} \mathrm{Q} * * \mathrm{C} *$ & $\mathrm{~L}^{* * *} \mathrm{C}^{* *}$ & $\mathrm{~L}^{* * *} \mathrm{Q}^{* * *} \mathrm{C}^{* *}$ \\
\hline Calcium & $\mathrm{L}^{* * *} \mathrm{Q}^{* *} \mathrm{C}^{*}$ & $\mathrm{~L}^{* * *} \mathrm{Q} * * *$ & $\mathrm{~L}^{* * *} \mathrm{C}^{*}$ & $\mathrm{~L}^{* * *}$ & $\mathrm{Q}^{* *} \mathrm{C}^{*}$ \\
\hline Magnesium & $\mathrm{L}^{* *} \mathrm{Q} * *$ & $\mathrm{~L}^{* *} \mathrm{Q}^{* *}$ & $\mathrm{~L}^{* * *} \mathrm{Q} * * *$ & $\mathrm{~L}^{* * *} \mathrm{Q} *$ & $\mathrm{~L}^{* * *}$ \\
\hline
\end{tabular}

${ }^{\mathrm{z}} \mathrm{L}=$ linear trend; $\mathrm{Q}=$ quadratic trend; $\mathrm{C}=$ cubic trend.

Ns, * **, *** Nonsignificant and significant at $P<0.05, P<0.01$, and $P<0.001$, respectively.
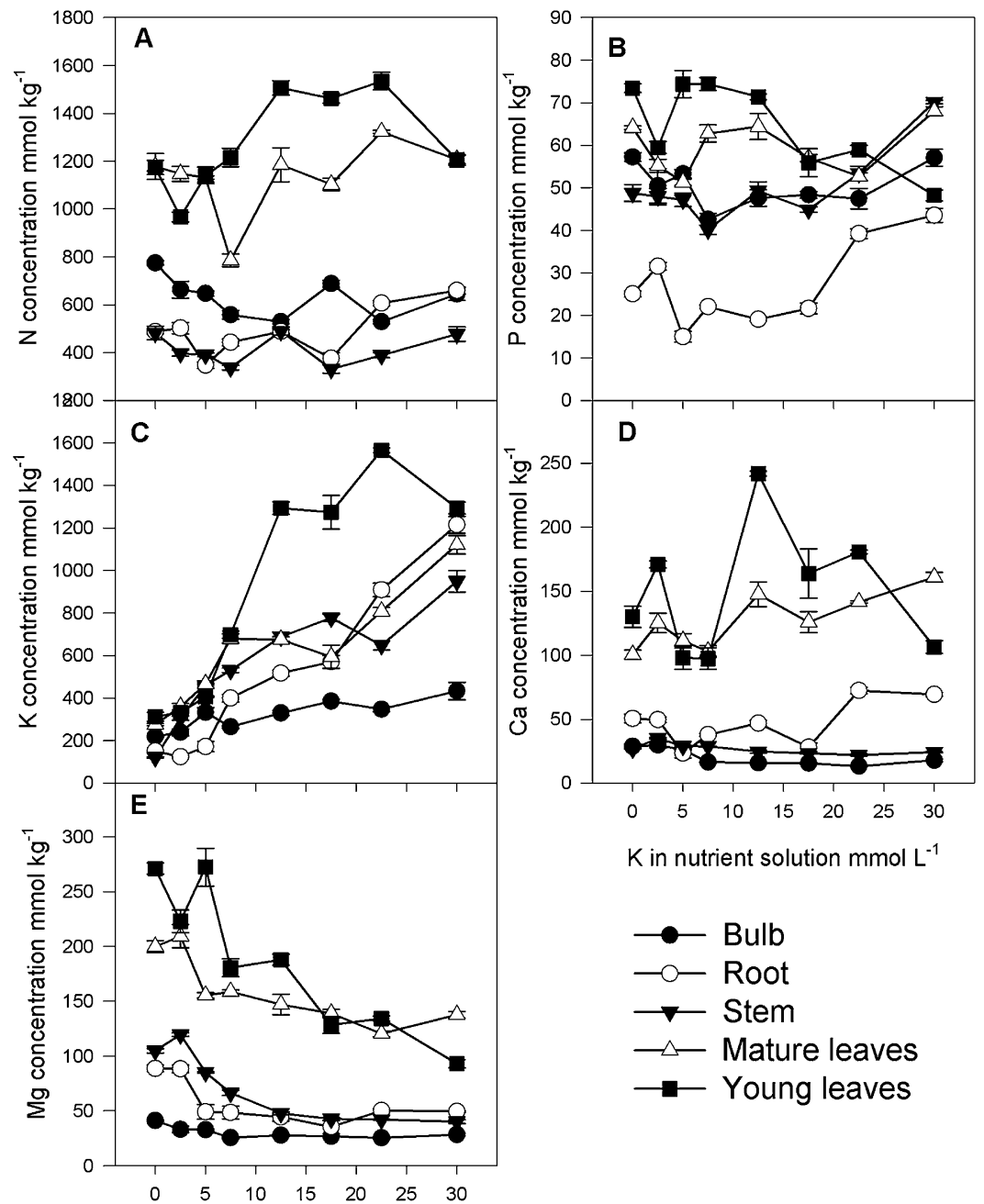

$\mathrm{K}$ in nutrient solution $\mathrm{mmol} \mathrm{L}^{-1}$

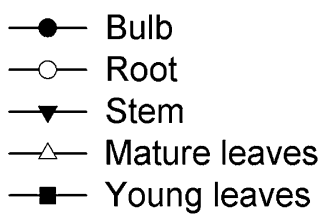

$\mathrm{K}$ in nutrient solution $\mathrm{mmol} \mathrm{L}^{-1}$

Fig. 3. Concentration of nitrogen $(\mathrm{N})$, phosphorus $(\mathrm{P})$, potassium $(\mathrm{K})$, calcium $(\mathrm{Ca})$, and magnesium $(\mathrm{Mg})$ at experiment termination in Lilium sp. L. cv. Arcachon plant organs fertigated with 0 to $30 \mathrm{mmol} \cdot \mathrm{L}^{-1}$ $\mathrm{K}$. Bars represent the SEM.

Net photosynthetic rate was affected by $\mathrm{K}_{\text {ext }}$ in both young and mature leaves but no significant trend was observed in mature leaves, whereas in young leaves, photosynthetic rate increased as $\mathrm{K}_{\text {ext }}$ increased from 0 to $5 \mathrm{mmol} \cdot \mathrm{L}^{-1}$ (Table 4 ). When averaged across $\mathrm{K}_{\mathrm{ext}}$ concentration, photosynthetic rates were greater in young leaves when compared with mature leaves at $\mathrm{K}_{\text {ext }}$ less than $7.5,12.5$, and $30 \mathrm{mmol} \cdot \mathrm{L}^{-1}$. Leaf $\psi_{\mathrm{w}}$ increased in both young and mature leaves with $\mathrm{K}_{\mathrm{ext}}$ increased after a linear or quadratic trend (Table 4). Higher chlorophyll content (SPAD index) was detected on young leaves;
Decreased $\mathrm{K}$ accumulation at high $\mathrm{K}_{\text {ext }}$ may be the result of a decreased uptake rate, probably related with a high-affinity and low-affinity K-uptake system (Britto and Kronzucker, 2008; Rengel and Damon, 2008).

The two critical concentrations in the shoot were defined in the present study by segmented analysis using $\mathrm{K}_{\text {int }}$ because plant responses better fit the models when compared with models using $\mathrm{K}_{\text {ext }}$ concentrations. Critical concentrations varied according to the growth parameter selected; optimum $\mathrm{K}_{\text {int }}$ ranged from 303 to $384 \mathrm{mmol} \cdot \mathrm{kg}^{-1}$ for vegetative plant parts, whereas optimum flower growth (diameter and DM) ranged from 427 to $504 \mathrm{mmol} \cdot \mathrm{kg}^{-1}$. Thus, higher $\mathrm{K}$ is required for maximum flower quality.

Internal $\mathrm{K}$ at $504 \mathrm{mmol} \cdot \mathrm{kg}^{-1}$ was associated with optimum growth for all the parameters assessed; however, $\mathrm{K}_{\text {int }}$ greater than 864 $\mathrm{mmol} \cdot \mathrm{kg}^{-1}$ was associated with a decline in all growth parameters. Thus, these may be considered as the critical optimum and toxicity concentrations, respectively. The high $\mathrm{K}_{\mathrm{int}}$ concentrations were achieved with nutrient solutions with the highest $\mathrm{K}$ and $\mathrm{EC}$; however, we suggest that the growth decline is not the result of the osmotic effects because plants irrigated with these solutions had the highest leaf $\psi_{\mathrm{w}}$. In addition, when the data for plants grown with solutions containing $\mathrm{K}$ at $30 \mathrm{mmol} \cdot \mathrm{L}^{-1}$ were removed from the segmented analysis to avoid the possibility of osmotic effects or excess sulfate resulting from high $\mathrm{K}_{\text {ext }}$ concentrations, the estimated models (not shown) were poor in detecting the critical toxic level. The models for shoot $\mathrm{K}$ in response to $\mathrm{K}_{\mathrm{ext}}$ indicate that optimum and toxic levels of $\mathrm{K}_{\mathrm{int}}, 504$ and $864 \mathrm{mmol} \cdot \mathrm{kg}^{-1}$, are achieved at 5.6 and $13.6 \mathrm{mmol} \cdot \mathrm{L}^{-1}$ of $\mathrm{K}$ in the nutrient solution, respectively.

The increased $\mathrm{K}$ in the younger leaves may have been associated with increased $\psi_{\mathrm{w}}$ as a result of the effect of $\mathrm{K}$ on uptake, transport, and compartmentalization of water and solutes (Marschner, 1995). In turn, water accumulation may have increased turgor pressure and allowed maximum cell extension, leading to increased flower and cell size, as suggested by the lower number of chlorenchyma and occlusive cells observed per unit area. Potassium has been reported to contribute to cell enlargement and leaf expansion (Fricke et al., 1994; Fricke and Flowers, 1998; Shabala, 2003; Shabala et al., 2000). An increase in leaf size in Guzmania lingulata (L.) Mez (Yi Lin and Ming Yeh, 2008), Olea europea L. (Karimi et al., 2009), and Phalaenopsis Blume (Wang, 2007) as well as a higher $\psi_{\mathrm{w}}$ in Hibiscus rosa-sinensis L. (Egilla et al., 2005) have been reported with supplementary $\mathrm{K}$ application. Young leaves exhibited increased $\mathrm{N}$ as $\mathrm{K}_{\mathrm{ext}} 12.5 \mathrm{mmol} \cdot \mathrm{L}^{-1}$ or greater. Higher $\mathrm{N}$ in young leaves at a $\mathrm{K}$ sufficient range was probably the result of the requirement of $\mathrm{K}$ for the translocation of $\mathrm{NO}_{3}{ }^{-}$from the root to the aboveground portions of the plant (Mengel and Kirkby, 2001).

Our results showed that $\mathrm{N}$ concentrations in mature and young leaves were comparable to the recommended nutrient status for 
Table 3. Anatomic characteristics of young leaves of Lilium sp. L. cv. Arcachon grown in perlite and fertigated with solutions of increasing potassium (K) concentration.

\begin{tabular}{|c|c|c|c|c|c|c|c|}
\hline $\begin{array}{l}\mathrm{K} \text { in nutrient } \\
\text { solution } \\
\left(\mathrm{mmol} \cdot \mathrm{L}^{-1}\right)\end{array}$ & $\begin{array}{c}\text { Leaf } \\
\text { thickness }(\mu \mathrm{m})\end{array}$ & $\begin{array}{l}\text { Chlorenchyma } \\
\left(\text { cells per } \mathrm{mm}^{2} \text { ) }\right.\end{array}$ & $\begin{array}{c}\text { Metaxylem } \\
\text { vessel count }\end{array}$ & $\begin{array}{c}\text { Metaxylem } \\
\text { vessel diam. }(\mu \mathrm{m})\end{array}$ & $\begin{array}{c}\text { Stomata } \\
\left(\text { count per } \mathrm{mm}^{2}\right)\end{array}$ & $\begin{array}{l}\text { Occlusive cell } \\
\text { length }(\mu \mathrm{m})\end{array}$ & $\begin{array}{c}\text { Occlusive cel } \\
\text { width }(\mu \mathrm{m})\end{array}$ \\
\hline 0 & 573 & 52.5 & 9.0 & 27.9 & 44.8 & 93.6 & 54.5 \\
\hline 5 & 606 & 45.0 & 6.0 & 30.7 & 38.0 & 103.9 & 53.6 \\
\hline 12.5 & 660 & 38.3 & 8.3 & 30.8 & 29.3 & 105.8 & 55.6 \\
\hline 17.5 & 647 & 35.8 & 6.0 & 30.2 & 39.0 & 99.9 & 52.7 \\
\hline 30 & 564 & 48.8 & 6.8 & 30.1 & 36.2 & 94.3 & 51.1 \\
\hline ANOVA $^{z}$ & $P<0.001$ & $P<0.001$ & $P<0.318$ & $P<0.344$ & $P<0.001$ & $P=0.001$ & $P=0.170$ \\
\hline Trend analysis ${ }^{\mathrm{y}}$ & $\mathrm{Q}^{* * *}$ & $\mathrm{Q}^{* * *}$ & NS & NS & $\mathrm{L}^{*} \mathrm{Q} * * \mathrm{C}^{* *}$ & $\mathrm{Q}^{* * *} \mathrm{C} * *$ & NS \\
\hline
\end{tabular}

${ }^{\mathrm{z}}$ Analysis of variance.

${ }^{\mathrm{y}} \mathrm{L}=$ linear trend; $\mathrm{Q}=$ quadratic trend; $\mathrm{C}=$ cubic trend.

NS, $* * *, * * *$ Nonsignificant and significant at $P<0.05, P<0.01$, and $P<0.001$, respectively.

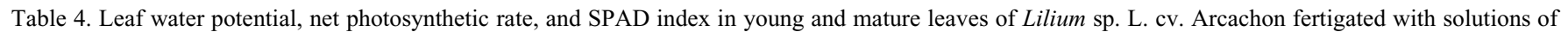
increasing potassium $(\mathrm{K})$ concentration.

\begin{tabular}{|c|c|c|c|c|c|c|}
\hline \multirow{2}{*}{$\begin{array}{l}\mathrm{K} \text { in nutrient } \\
\text { solution }\left(\mathrm{mmol} \cdot \mathrm{L}^{-1}\right)\end{array}$} & \multicolumn{2}{|c|}{ Water potential $(\mathrm{MPa})$} & \multicolumn{2}{|c|}{ Net photosynthetic rate $\left(\mu \mathrm{mol} \mathrm{CO} \mathrm{CO}_{2} / \mathrm{m}^{-2} \cdot \mathrm{s}^{-1}\right)$} & \multicolumn{2}{|c|}{ SPAD index } \\
\hline & Young leaves & Mature leaves & Young leaves & Mature leaves & Young leaves & $\overline{\text { Mature leaves }}$ \\
\hline 0 & $-0.532^{* z}$ & -0.417 & $24.6^{*}$ & 17.5 & $73.9 * * *$ & 65.4 \\
\hline 2.5 & $-0.604 \mathrm{NS}$ & -0.528 & $27.2 *$ & 15.8 & $73.4 * * *$ & 65.0 \\
\hline 5 & $-0.464 \mathrm{NS}$ & -0.451 & $28.0 *$ & 13.9 & $73.3 * *$ & 64.8 \\
\hline 7.5 & $-0.414 \mathrm{NS}$ & -0.439 & $20.6 \mathrm{NS}$ & 24.0 & $73.1 * * *$ & 65.8 \\
\hline 12.5 & $-0.429 \mathrm{NS}$ & -0.476 & $25.7 *$ & 13.0 & $72.4 * * *$ & 65.4 \\
\hline 17.5 & $-0.550 \mathrm{NS}$ & -0.514 & $23.0 \mathrm{NS}$ & 18.1 & $71.2 * * *$ & 63.6 \\
\hline 22.5 & $-0.230 *$ & -0.281 & $22.1 \mathrm{NS}$ & 15.8 & $70.0 * * *$ & 64.0 \\
\hline 30 & $-0.183 \mathrm{NS}$ & -0.187 & $28.8^{*}$ & 10.5 & $69.5 * * *$ & 63.5 \\
\hline ANOVA $^{\mathrm{y}}$ & $P<0.001$ & $P<0.001$ & $P<0.033$ & $P<0.049$ & $P<0.002$ & $P=0.282$ \\
\hline Trend analysis ${ }^{\mathrm{x}}$ & $\mathrm{L}^{* * *} \mathrm{Q}^{*}$ & $\mathrm{~L}^{* * *} \mathrm{Q} * * *$ & $\mathrm{Q}^{*}$ & NS & $\mathrm{L} * * *$ & NS \\
\hline
\end{tabular}

${ }^{\mathrm{z}}$ Mean comparison across young and mature leaves.

${ }^{\mathrm{y}}$ Analysis of variance.

${ }^{\mathrm{x}} \mathrm{L}=$ linear trend; $\mathrm{Q}=$ quadratic trend.

NS, *,*** Nonsignificant and significant at $P<0.05$ and $P<0.001$, respectively.

good-quality lilium plants, as stated previously (Dole and Wilkins, 2005). However, N content reported for all other plant parts was below recommended levels. Phosphorus was within the recommended range (Dole and Wilkins, 2005) in all plant parts, except for roots, and $\mathrm{K}$ was within the recommended range when $\mathrm{K}_{\text {ext }}$ was $7.5 \mathrm{mmol} \cdot \mathrm{L}^{-1}$ or higher. Calcium in the mature and young leaves was above suggested concentrations, whereas $\mathrm{Mg}$ was within the range in the mature and young leaves and stems at low $\mathrm{K}_{\text {ext }}$ levels.

Potassium increased in young leaves and roots when $\mathrm{K}_{\text {ext }}$ was $12.5 \mathrm{mmol} \cdot \mathrm{L}^{-1}$ or greater. Higher $\mathrm{K}$ in young leaves was associated with higher chlorophyll content, as suggested by the higher SPAD index, whereas the mature leaves exhibited a decrease in $\mathrm{Mg}$ as $\mathrm{K}$ increased, probably as a result of antagonism between these nutrients (Qi and Spalding, 2004; Rus et al., 2004; Spalding et al., 1999) as observed in our study.

Photosynthetic rates were higher in young leaves when compared with mature leaves, which was probably the result of the higher chlorophyll content; however, this was not observed in plants supplemented with $\mathrm{K}_{\text {ext }}$ concentrations close to the estimated optimum levels $\left(7.5 \mathrm{mmol} \cdot \mathrm{L}^{-1}\right)$. Plants with a limited supply of $\mathrm{K}_{\text {ext }}$ exhibited a lower photosynthetic rate in mature leaves, which may be associated with the lower concentration of $\mathrm{K}_{\mathrm{int}}$ as a result of $\mathrm{K}$ mobilization to the younger organs when deficiency levels of $\mathrm{K}_{\mathrm{ext}}$ were imposed. Photosynthetic rate did not exhibit a clear tendency in response to $\mathrm{K}_{\text {ext }}$, probably as a result of the nutrient imbalances that resulted from either low or excessive $\mathrm{K}$ uptake as well as the interaction of $\mathrm{K}$ with the uptake of other nutrients such as $\mathrm{Mg}, \mathrm{P}$, and $\mathrm{NO}_{3}{ }^{-}$.

\section{Conclusions}

Under the experimental conditions in which this study was conducted, the critical optimum $\mathrm{K}$ concentration in the shoots of Lilium was estimated at $504 \mathrm{mmol} \cdot \mathrm{kg}^{-1}$, whereas the critical toxicity level was at $864 \mathrm{mmol} \cdot \mathrm{kg}^{-1}$; these internal $\mathrm{K}$ concentrations were estimated to occur when $\mathrm{K}$ in the nutrient solution was at 5.6 and $13.6 \mathrm{mmol} \cdot \mathrm{L}^{-1}$, respectively. Optimum growth at the critical optimum level was associated with increased cell enlargement as a result of increased leaf $\psi_{\mathrm{w}}$. Photosynthetic rates were lower in the mature leaves when compared with the younger leaves, which may be the result of decreased $\mathrm{K}$ when plants were subjected to suboptimal $\mathrm{K}$ or decreased $\mathrm{Mg}$.

\section{Literature Cited}

Amtmann, A., S. Troufflard, and P. Armengaud. 2008. The effect of potassium nutrition on pest and disease resistance in plants. Physiol. Plant. 133:682-691.

Argo, W.R. and J.A. Biernbaum. 1994. Irrigation requirements, root-medium $\mathrm{pH}$, and nutrient concentrations of easter lilies grown in five peat-based media with and without an evaporation barrier. J. Amer. Soc. Hort. Sci. 119: $1151-1156$
Armengaud, P., R. Sulpice, A.J. Miller, M. Stitt, A. Amtmann, and Y. Gibon. 2009. Multilevel analysis of primary metabolism provides new insights into the role of potassium nutrition for glycolysis and nitrogen assimilation in Arabidopsis roots. Plant Physiol. 150:772-785.

Bremner, J.M. 1996. Nitrogen-total, p. 1085-1121. In: Bigham, J.M. (ed.). Methods of soil analysis. Soil Science Society of America, Madison, WI.

Britto, D.T. and H.J. Kronzucker. 2008. Cellular mechanism of potassium transport in plants. Physiol. Plant. 133:637-650.

Dole, J.M. and H.F. Wilkins. 2005. Floriculture, principles and species. 2nd Ed. Prentice Hall, NJ.

Egilla, J.N., F.T. Davies, and T.W. Boutton. 2005 Drought stress influences leaf water content, photosynthesis, and water-use efficiency of Hibiscus rosa-sinensis at three potassium concentrations. Photosynthetica 43:135-140.

Fricke, W. and T.J. Flowers. 1998. Control of leaf cell elongation in barley. Generation rates of osmotic pressure and turgor, and growthassociated water potential gradients. Planta 206:53-65.

Fricke, W., R.A. Leigh, and A.D. Tomos. 1994. Concentrations of inorganic and organic solutes in extracts from individual epidermal, mesophyll and bundle-sheath cells of barley leaves. Planta 192:310-316.

Genc, Y., G.K. McDonald, and R.D. Graham. 2002. Critical deficiency concentration of zinc in barley genotypes differing in zinc efficiency and its relation to growth responses. J. Plant Nutr. 25:545-560.

Isaac, M.E. and A.A. Kimaro. 2011. Diagnosis of nutrient imbalances with vector analysis in agroforestry systems. J. Environ. Qual. 40: 860-866. 
Karimi, E., A. Abdolzadeh, and H.R. Sadeghipour. 2009. Increasing salt tolerance in Olive, Olea europaea L. plants by supplemental potassium nutrition involves changes in ion accumulation and anatomical attributes. Intl. J. Plant Prod. 3:49-60.

Marschner, H. 1995. Mineral nutrition of higher plants. 2nd Ed. Academic Press, Inc., London, UK.

Mengel, K. and E.A. Kirkby. 2001. Principles of plant nutrition. 5th Ed. Kluwer Academic Publishers, The Netherlands.

Qi, Z. and E.P. Spalding. 2004. Protection of plasma membrane $\mathrm{K}^{+}$transport by the salt overly sensitive1 $\mathrm{Na}^{+}-\mathrm{H}^{+}$antiporter during salinity stress. Plant Physiol. 136:2548-2555.

Rengel, Z. and P.M. Damon. 2008. Crops and genotypes differ in efficiency of potassium uptake and use. Physiol. Plant. 133:624636.
Rus, A., B. Lee, A. Muñoz-Mayor, A. Sharkhuu, K. Miura, J.K. Zhu, R.A. Bressan, and P.M. Hasegawa. 2004. AtHKT1 facilitates $\mathrm{Na}^{+}$homeostasis and $\mathrm{K}^{+}$nutrition in planta. Plant Physiol. 136:2500-2511.

Salifu, K.F. and V.R. Timmer. 2003. Optimizing nitrogen loading of Picea mariana seedlings during nursery culture. Can. J. For. Res. 33:1287-1294.

Shabala, S. 2003. Regulation of potassium transport in leaves: From molecular to tissue level. Ann. Bot. (Lond.) 92:627-634.

Shabala, S., O. Babourina, and I. Newman. 2000. Ion-specific mechanisms of osmoregulation in bean mesophyll cell. J. Expt. Bot. 51:12431253.

Soltanpour, P.N., G.W. Johnson, S.M. Workman, J. Benton Jones, and R.O. Miller. 1996. Inductively coupled plasma emission spectrometry and inductively coupled plasma-mass spec- trometry, p. 91-139. In: Bigham, J.M. (ed.). Methods of soil analysis. Soil Science Society of America, Madison, WI.

Spalding, E., R.E. Hirsch, D.R. Lewis, Z. Qi, M.R. Sussman, and B.D. Lewis. 1999. Potassium uptake supporting plant growth in the absence of AKT1 channel activity: Inhibition by ammonium and stimulation by sodium. J. Gen. Physiol. 113:909-918.

Ulrich, A. and F.J. Hills. 1993. Principles and practices of plant analysis, p. 11-24. In: Westerman, R.L. (ed.). Soil testing and plant analysis. Part II. Soil Sci. Soc. Amer., Madison, WI.

Wang, Y.T. 2007. Potassium nutrition affects growth and flowering of Phalaenopsis grown in a bark mix or sphagnum moss substrate. HortScience 42:1563-1567.

Yi Lin, C. and D. Ming Yeh. 2008. Potassium nutrition affects leaf growth, anatomy, and macroelements of Guzmania. HortScience 43:146-148. 